by Robert L Nusbaum, Ronald W Girdler, James R Heirtzler, Duncan J Hutt, David Green, Victor E Millings, Bradley S Schmoll and Joel Shapiro

\title{
The distribution of earthquakes and volcanoes along the East African Rift system
}

The pattern of earthquake epicentres for the period 1904 to 1993 is compared with the distribution of 615 Cenozoic volcanoes in the East African Rift system. Holocene volcanism occurs mostly within the rift valleys while the preHolocene volcanoes are more scattered and extend beyond the confines of the rift. Pre-Holocene volcanism is also more extensive, reaching south through Mozambique and Zimbabwe. Most of the volcanoes, of all ages, are associated with the eastern branch of the rift system. In contrast, the western branch appears to be far more seismically active than its eastern counterpart, although most of the epicentres postdate 1963. In general, teleseismic earthquake epicentre data for 1904 through 1993 (noting the short time period) and Holocene volcanism show no apparent simple relationship except for the Ethiopian Rift.

\section{Introduction}

The East African Rift system was first recognised as a continental rift system in the last century (Suess. 1891; Gregory, 1896, 1921). Extensive coverage by satellite remote sensing offers a unique opportunity to study its major tectonic and geological features. Whilst imagery from the rift system has been discussed by Mohr (1974), who presented lineament maps using imagery from the first Landsat satellite (ERTS-1), no previous study has used newer data and covered the entire East African Rift system from the Red Sea southwards. There has been no extensive comparison of the seismicity with distribution of volcanoes which dominate much of the landscape in the region. The distributions of teleseismic events and volcanoes are discussed here, as they offer some insight into rifting processes. The rift is usually defined by its geomorphic expression, i.c. opposite-facing scarps across a grabentype structure and by general topographic uplift of the shoulders and margins (figure 1).

Figure I Location of major features along the East African Rift.

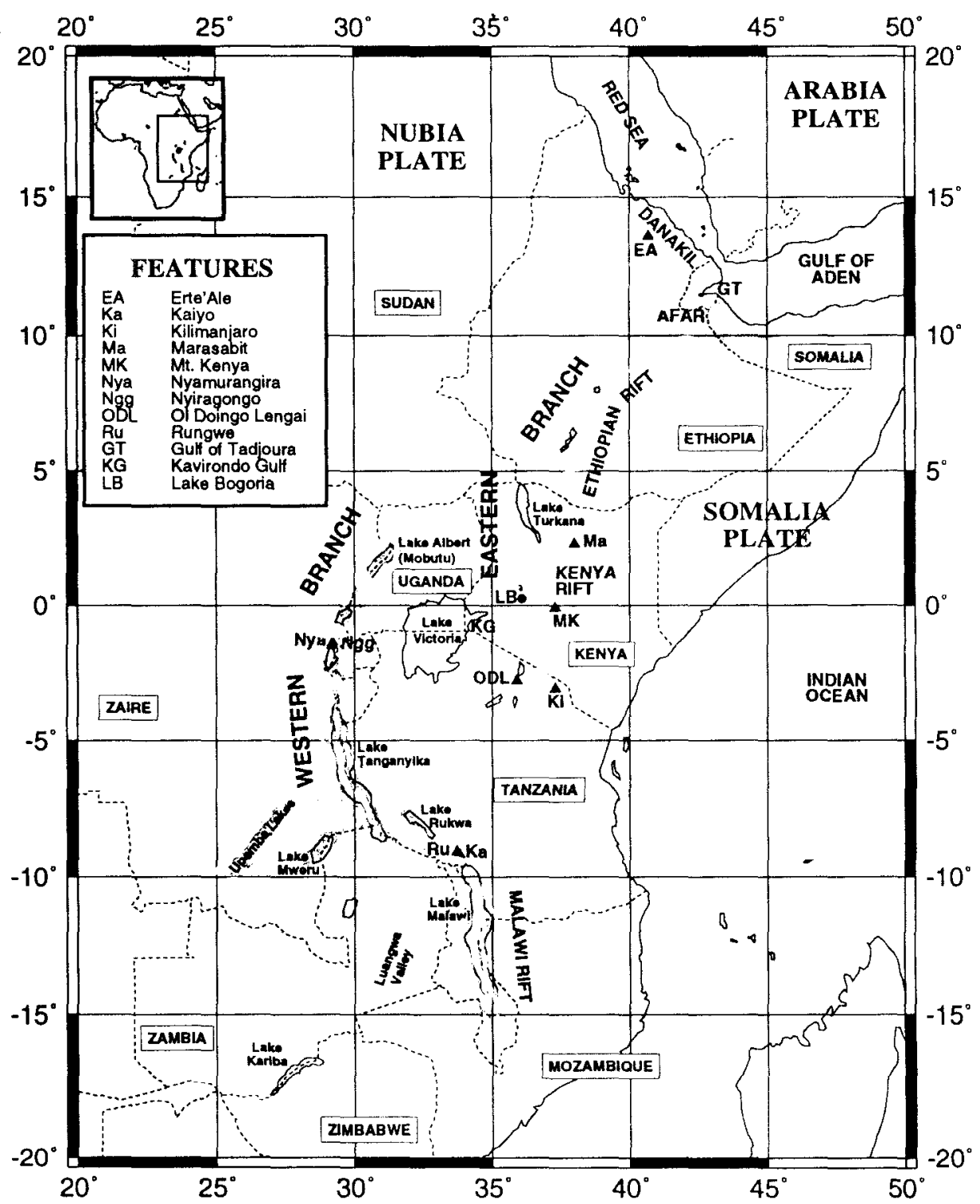

Nlthough the axis of the eastern branch of the rift system is thought to be an incipient, accreting plate margin between the Nubia and Somali plates (Girdler and others. 1969), the boundary between the plates is complex: at the northern end is the Alar triple junction with the Arabian plate to the northeast and the Nubia and Somali plates to the west and south: south of Alar, the Ethiopian Rift is covered with volcanic rocks which become less continuous in Kenya. Further south, in Tanzania, the single rift becomes several branching rifts. In addition, the eastern and western branches seem, at least in part, to enclose another plate, with Lake Victoria near its middle. Some sectors are more active than others at the present time and some have, undoubtedly, been more active in the past. The episodic nature of seismic activity and the segmentation of the rift, producc 
complex leatures in the continental crust. The distribution of voleanic activity, however, reflects more-deep-seated land possibly less-complex) processes which can be used to identify major lectonic processes. Prior studies of volcanism have provided tenporal and spatial constraints on the evolution of various rilt segments. Kazmin and oth ers (1980) and Zaneetin and others (1980) report that Eocene to Mio cene volcanism occurred on the Ethiopian Plateau, west of the rift. Ethiopian volcanism since that time has been largely confined to the rilt, or to northwestern Atar. along the transverse-trending Dubbi line and the Erta Ale Range to the west. Others (Cahen and others, 1984) have used regional temporal variations in volcanism along various East African Rift segments to provide details of rift segment evolulion. In Kenya the voleanism began 38 Ma ago west of Lake Turkana. becoming concentrated within the Kenya Rift during the Miocene Holocene (e.g. Girdler and others. 1969: Baker and others. 1971; Batker and others, 1972; King, 1978: Morley and others, 1992; Wilkinson. 1988). Western branch volcanism commenced 12 Ma ago in the northern part and has continued to the present (c.g. Ebinger. 1989). The compilations of Holocene $(<10000$ ybp) volcanoes at the Smithsonian Inslitution have proved useful towards establishing their distribution relative to the entire bast African Rift axis (Simkin and others. 1981: Simkin and others. 1989: Moclelland and others, 1989). These do not extend back to the pre-Holocene and hence give limited information on the geologic evolution.

\section{Seismicity}

Detailed world-wide seismicity dalta have been available only since the introduction of the World-wide Standard Seismograph Net (WWSSN) at the becinning of 1964. Since January 1964. the International Seismological Centre (ISC) has published determinations of carthquake epicentres that are usually accurate !o withen 0.1 (athout

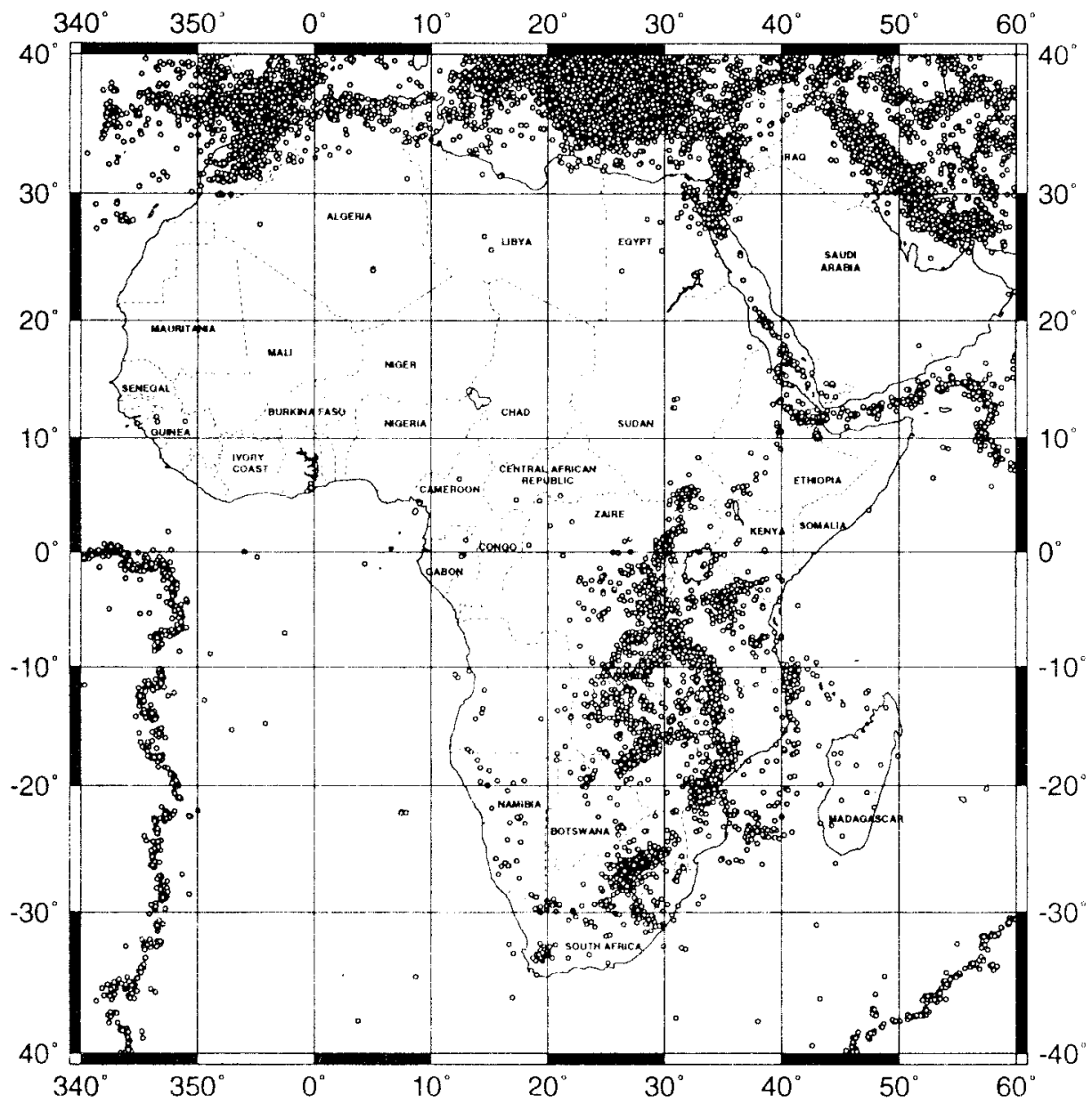

$10 \mathrm{~km}$. Prior to 1964, various agencies published data but these aro generally less accurate exept for large earthquakes. The pre- 1964 cvents are included here as they are sufficiently accurate for comparisons with the volcanism: these are from Gutenbery and Richter (1954) for 1906 to 1952; the International Seismological Summary for 1913 to 1963; and Bureau Central International de Séismologie for 1950 to 1963. Figure 2 is an overview of the seismicity of Africa using ISC-determined epicentres 11964 to 1991). Figure 5a shows the seismicity of East Africa compared with the Holocene and preHolocene volcanoes (figures $5 b$ and $c$ ). Most of the events are of small magnilude; only nine cvents exceed magnitude 6 , the laresest being in southern Sudan on 20 May 1990. with body wave magnitude 6.5 and surface wave magnitude 7.2 .

The most noticeable feature in figures 2 and $5 \mathrm{a}$ is the large number of eathquakes along the westem branch of the rift system and the relative lack of teleseismic activity in the castern branch. The scismically active region in the eastern branch extends from north of lake Albert (Mobutu) to south of Lake Malawi, with several possible side branches extending in a southwesterly direction. The most pronounced of these start at about $6^{\circ} \mathrm{S}, 7.5^{\circ} \mathrm{S}$ and $10^{\circ} \mathrm{S}$. The first includes the Upemba lakes, the second. I ake Mweru, and the third runs southwest along the Luangwa River to Lake Kariba both of which are thought to occupy pre-Tertiary rifts (e.g. Rosendahl, 1987). The large number of events at about 17 'S. 28 E are related to loading associated with the Kariba Dam (Faithead and Girdler, 1971). A study of the recent (1991) carthquake swarm in southern Sulan (McConnell 1992) suggests an extension of the western branch to the north of I ake Albert along the Nile valley to about $6 \mathrm{~N}$. In contrast. the Kenya Rift appears to be seismically much quieter except for northern Tanzania. This may he due to the short period of the data set, most of the events documented heing post-1903. a period of only 30 years. On 6 January 192x, a large earthquake known as the Subukia carthquake (Gutenberg-Richter magnitude 7.0) struck the Late Bogoria (Hannington) area of Kenyal and there has been some recent teleseismic activity just to the south of this region. The region is microseismicially active te.g. Tongue and others. 1992) and famous for its hot spring activity. Ioupekine (1971) in his (atalogue of Felt Earthquakes in Kenya lists 567 earthquakes for the period 1892 to 1969: many of these tend to be on or near the eastern scarp of the Kenya Ritt and in the Kavirondo Gulf region in western kenya.

\section{Volcanoes}

Most of the data for the location of volca noes come from an examination of satellite images. The areal extent of the imagery is shown in figure 3 . It is either Landsat 4 multispectral scanner (MSS) or Landsat 5 thematic mapper (TM): these have resolutions of $80 \mathrm{~m}$ and $30 \mathrm{~m}$. respectively. TM scenes were used mostly for Ethiopia: MSS mosaics were used between northern Kenya (Lake Turkana) and northern Tanzania; individual MSS seenes were used for the remainder.

Volcanoes have been classilied as Holocene and pre-Holocene. Using the criteria of Simkin and others (1981). Holocene volcanoes are those which either have dated cruptions within the past 10000 years. or

Figure 2 ISC-determined epicentres for Africa for the period from January 1964 to May 1991 (all events with number of recording stations $N>5$ ). 


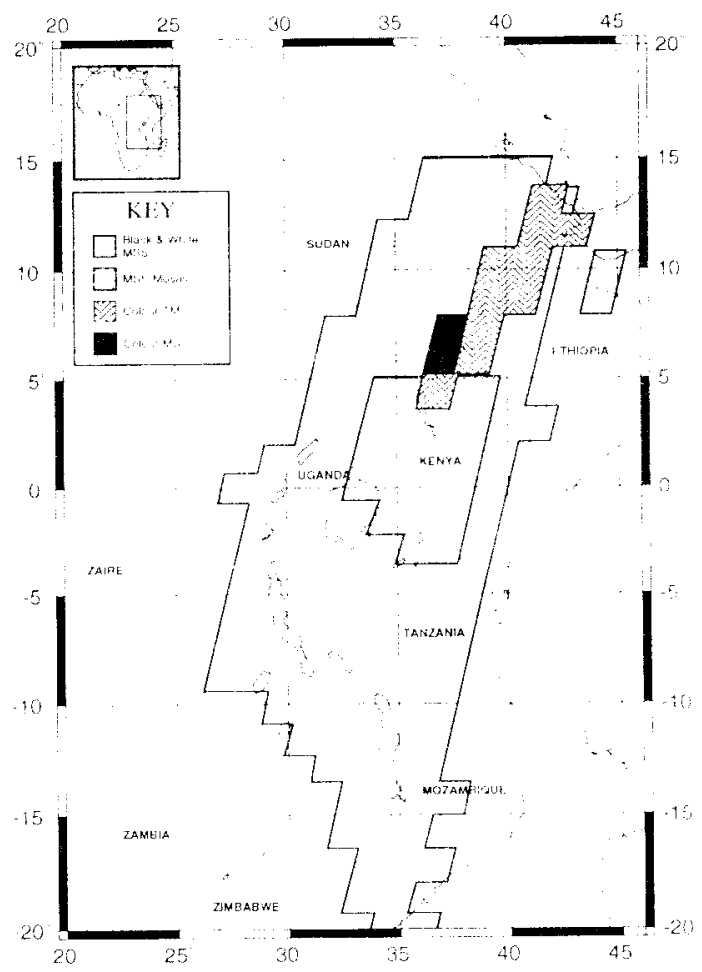

Figure 3 Coverage of various satellite remotesensing imagery used in the location of volcanoes.

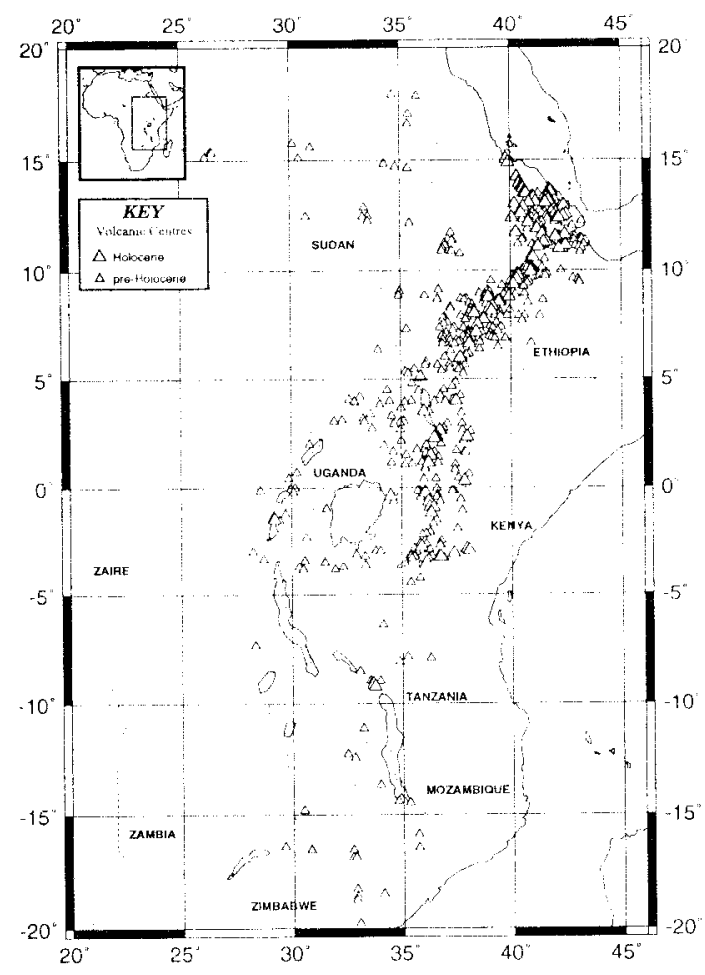

Figure 4 Holocene and pre-Holocene volcanoes of East Africa. Locations of Holocene volcanoes from Simkin and others $(1981,1989)$ and Mc Clelland and others (1989).

\section{Comparison of volcano and epicentre distributions}

Under the assumption that the epicentre distribution has not changed much over the last 10000 years. a comparison can tirst be made of the epicentre focations and the location of Holocene rolcanoes (ligures 5a and b), and how each of these relate to the rift structures.

The sprealding axis of the Gulf of Aden shows the seismic activity and topographic expression characteristic of the midocean ridge system: however, ocanographic surveys are not sufficiently detailed to show whether or nol volcanoes exist on the ocean floor. This is not so for the southemmost Red Sea which has (from south to north) the vol canic islands of Perim. Gireat and Little Hanish. Zukur. the Zubair Group, and Jebel At Tair (Gass and others, 196.5 1973: Girdler, 197.3). Figure 5a shows that the epicentres seem 10 trend north on both sides of the Danakil block. i.c. in the southem Red Seat and in Afar between Nubiat and the Danakil block: from about $16^{\circ} \mathrm{N}$ they continue mostly atong the ax is of the Red Sea. In northern Ethopia, between $11^{\circ}$ and $15 \mathrm{~N}$ a line of youthful volcanie cones. the Erta Ale range, strikes northwest-southeast and is clearly visible on satellite imagery. Seimic activity is largely confmed to this range: the Gulf of Tadjoura and its land extension: and western Alar the Nubia scarp). The Ethiopian Rilt, stetching southwest from Afar at about $10 \mathrm{~N}$, 40 " $\mathrm{E}$ to about $6 \mathrm{~N}$ is a well-developed rift with an almosi continuous line of Holocene volcanic centres along the valley llwor and some seismicily. It is this section which appears to be most like the accreting margin of the mid-ocean rift system. In contrast to the flat-lying Alat, this whole region, excluding the rift valley itself. is mountainous and elevated for some $560 \mathrm{~km}$ to the west and 330 $\mathrm{km}$ to the east of the rift axis (figure 1). From about $6^{\circ} \mathrm{N}$ to Lake Turkana $(4$ N), the regional topography and well-dedined rift disappear, though the presence of volcanoes and seismicity suggest that there is some continuous rift structure. This may be connected with interference from the Mesozoic Central African rilt system (Jorgensen and Bosworth, 1989), which crosses the East African Rift system in this locality. An east-west topographic profile at about $2 \mathrm{~S}$. crossing the western branch of the rift system, Lake Victoria, and the eastern branch would lead one to think that the two branches are due to similar, tensional processes. However, the eastern and westem branches of the rift bordering the 'Victoria plate' exhibil some strongly contrasting characteristics. Both branches, except for the southern end of the eastern branch, show rift valley topography. However, the western branch has few volcanic centres. The eastem branch has volcanoes where the rift valley topography is well developed, but terminates at about $3^{\circ} \mathrm{S}$. where basin-and-range-type faults are prominent over a wider area. The rule seems to be that volcanoes form only near a rift valley, or graben. The presence of Holocene volcanoes indicates a nearby rilt, though the converse is not neces 

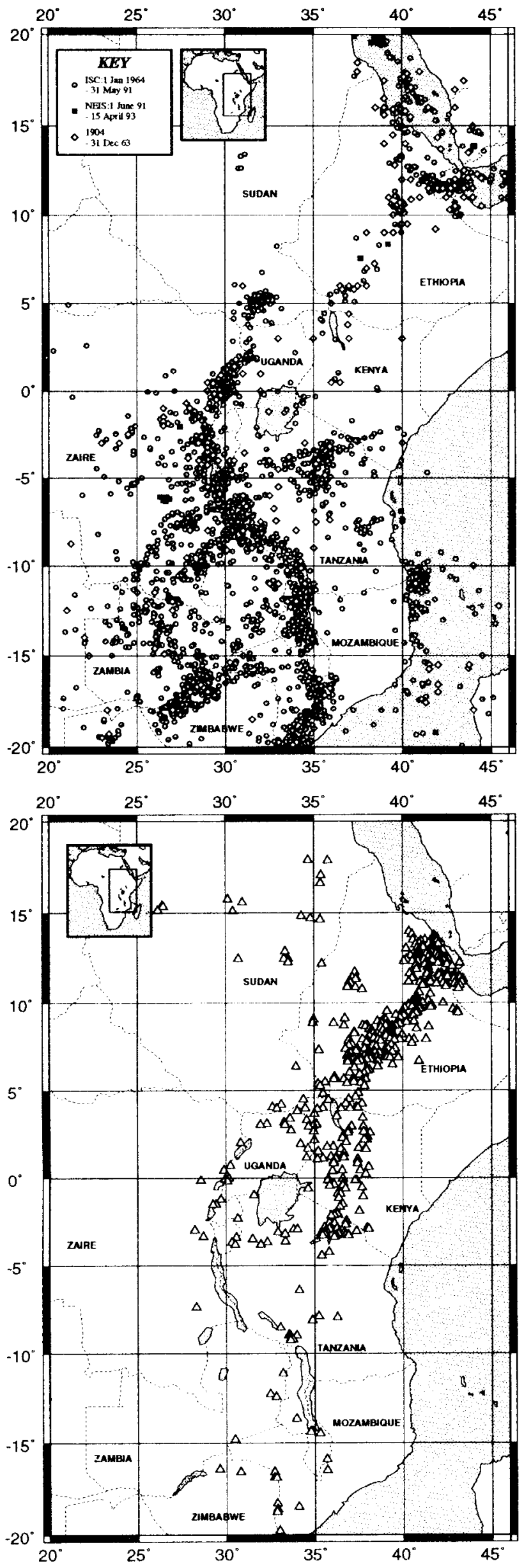

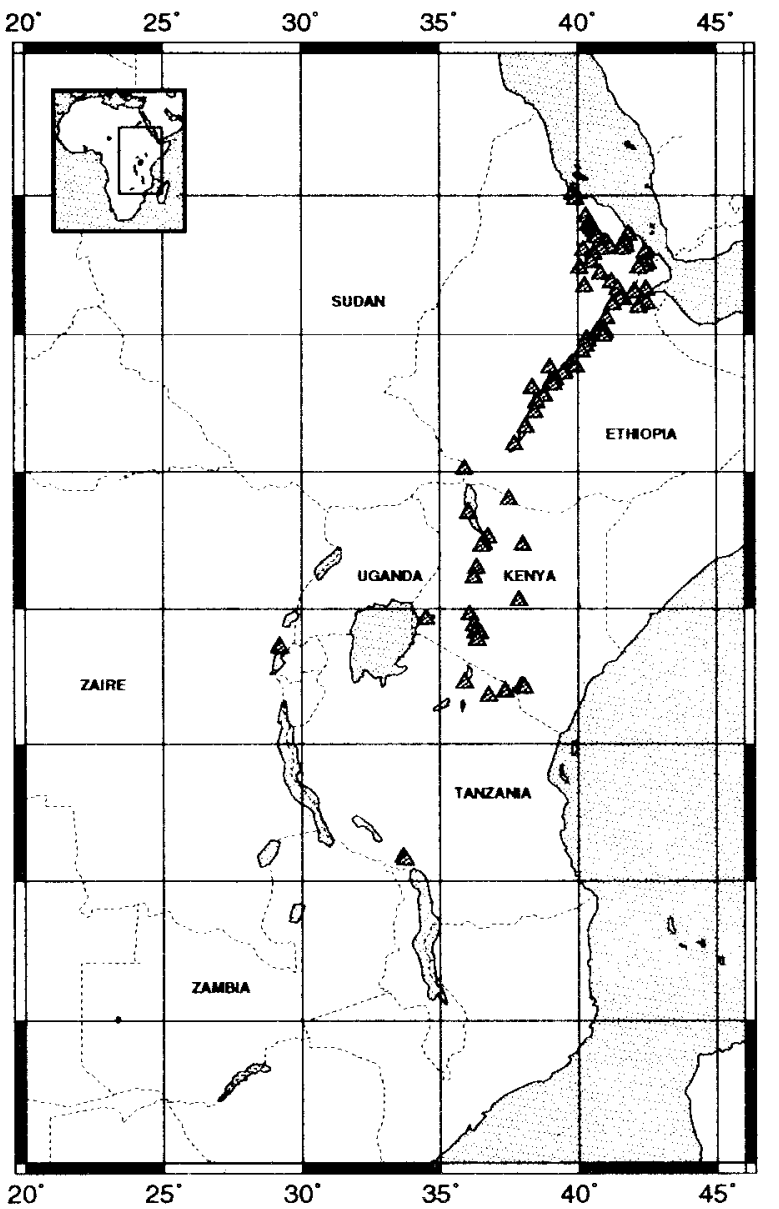

Figure 5 a above left Locations of earthquake epicentres; ISC (from January 1963 to May 1991) NEIS (June 1991 to April 1993) and various agencies (see text) data (1904 to December 1963).

\section{$b$ above Locations of Holocene volcanoes from Simkin and others (1981, 1989) and McClelland and others (1989).}

\section{c left locations of pre-Holocene volcanoes.}

sarily true. Scismicity, abundant in the entire western branch and in the southern end of the eastern branch. seems to be related to the volcano frequency, i.e, teleseismicity is low where the volcanicity is high and vice-versa. Near the southern end of the eastern branch, in northern Tanzania, there is a wide distribution of epicentres, but these are not continuous with the western branch, which is defined by Lakes Tanganyika. Rukwa and Malawi. Seismic activity on the eastern shoulder of these rifts is much less than to the west. Southwest-trending bands of epicentres extend from the western branch at about $6^{\circ} \mathrm{S} .7 .5^{\circ} \mathrm{S}$. and $10^{\circ} \mathrm{S}$. This seismic activity is more intense than along the Fthiopian rift, or the Kenya Rift, and seems to be related to propagating rift structures (Girdler, 1983, 1985, 1991). The preHolocene volcanoes (figure $5 c$ ) are much more widespread than those of the Holocene. Afar is densely covered and the trend continues through Ethiopia and Kenya. The symmetry of these about the Ethiopian rift is striking: they essentially form a broad band extending $200 \mathrm{~km}$ either side of the rift axis. This trend continues southwards past the Lake Turkana region, along the Kenya Rift and stops in northem Tanzania, as do the Holocene volcanoes (ef. figures 5 b and c). An important feature of the pre-Holocene volcanoes (tigure $\left.S_{c}\right)$ is the tendency to form two north-south lines in Kenyat. with one of these $100150 \mathrm{~km}$ east of the Kenya Rift. Other studies of volcanism along the Kenya Rift indicate that volcanism has migrated 
toward the rift since the Miocene (Girdler and others, 1969: Baker and others. 1972: King, 1978: Bellieni and others, 1986). Initially diffuse volcanism evolved in a similar manner along the Ethiopian rift (Mohr, 1983); as summarised by Chorowicz and others (1987), volcanism may have accompanied narrowing of the eastern branch (rifts) with time. All volcanism along the western branch is strikingly lower than along the eastern branch. Volcanic activity along the western branch was also scattered prior to the Holocene (figure $5 c)$ and became very much less during the Holocene.

\section{Magma volumes and 'off-axis' volcanism}

Differences in volcanism along the eastern and western branches have heen summarized (see Mohr, 1982). There are magmatic volume differences between the eastern branch and the western branch. Estimated eruptive volumes for the eastern branch are $144000 \mathrm{~km}^{3}$ in Kenya (Williams, 1972) and $345000 \mathrm{~km}^{3}$ in Ethiopia (Baker and others, 1972; Mohr, 1982). The western branch which has few volcanoes has been described as magmatically 'dry'. Figures $5 \mathrm{~b}$ and $c$ show that fewer than ten of the Cenozoic volcanoes are situated near the western branch. Volcanism has been restricted to the rift basins of the western branch for the past $10 \mathrm{Ma}$ (Ebinger, 1989). A similar pattern of volcanism generally applies to the older Kenya Rifi, although 'off-axis', Pliocene-Holocene volcanism is seen on the eastern shoulder $100-150 \mathrm{~km}$ from the rili axis (figure 5 b). Interest in "off-axis" volcanism is accentuated by the alignment of the imposing volcanoes. Kenya, Marsabit, and Kilimanjaro, the last being the largest in Africa. The cause of "off-axis' volcanism hals been the subject of considerable debate (Suess, 1891; Girdler and others, 1969; Bosworth, 1987: Morley, 1988; Ellis and King, 1991). Typically, the volcanoes analysed have been the enormous, late-Cenozoic volcanoes: Marsabit, Kenya. and Kilimanjaro. Our data indicate, however, that approximately 20 pre-Holocene volcanoes may be classified as "off-axis" (figure $5 \mathrm{c}$ ). Lithospheric thinning was suggested as an explanation for the symmetrical locations of large shield volcanoes on opposite tlanks of the Kenya Rift (Girdler and others, 1969. Searle 1970; Brown and Girdler, 1980) whilst Bosworth (1987) invoked thinning with intersecting detachment faults. The symmetry is lost, however, if the smaller volcanic sites are included in the analysis. Problems also arise from the Miocene age of Mount Elgon (west of the Kenya Rift) relative to proposed detachments (Morley, 1988). The "off-axis" linear trend in figure 4 suggests that volcanism was concentrated along older structures parallel to the Kenya Rilt. Although these older structures may have been important for allowing magma to erupt (Smith and Mosley, 1993; Dawson, 1992), the reason for the concentration of magma cast of the Kenya Rift remains unresolved. Hackman and others (1990) have suggested that the development of Plio-Pleistocene multicentred shields east of the Kenya Rift indicates an eastward shift in the manifestation of tensile stress. This could explain the 'off-axis' volcanism, but may conflict with the observed Holocene voleanism within the Kenya Rift, the focusing of volcanism into the Kenya Rift with time, and the observations indicating the whole of east Africa is associated with NW-SE extensional stress (Fairhead and Girdler, 1971).

\section{Concluding remarks}

Earthquake epicentres for 1904 through 1993 and spatial and temporal data for 516 pre-Holocene and 99 Holocene volcanoes extending along the entire East African Rift system have been presented. These indicate that pre-Holocene volcanism was much more scattered compared with Holocene volcanism, which is mostly focused in the rift valleys. "Off-axis" volcanism along the Kenya Rift occurred at approximately 20 volcanoes scattered along the entire length of the rift, suggesting fracturc-controlled magma conduits. Cross-correlation of teleseismic earthquake epicentre data for 1904 through 1993 (noting the short lime period) and Holocene volcanism, show no simple relationship except for the Ethiopian rilt.

\section{Acknowledgements}

Support lor this project was provided by the JOint VEnture (JOVL) program, the South Carolina Space Grant Consortium, and Marathon Oil Company. Landsat images were provided by NASA/Goddard Space Flight Center (GSFC) through the assistance of the Pilot Land Data System/Earth Resources Browse Facility, David Harding, and Herb W Blodget. We also wish to thank Mitchell Colgan for logistical and technical assistance. Tom Simkin kindly lent us the IAVCEI Data Sheet VIII, Post Miocene Volcanism of the World.

\section{References}

Anon, 1987, Geothermal reconnassance study of selected sites of the Ethiopian Rift system: Ethiopian Institute of Geological Surveys. Addis Ababa, lithiopial.

Baker, B H, Mohr. P'A, and Williams, I, A J, 1972, Geology of the castern rift system of Africa: Gololgical Socicty of America Special Paper no, 136.

Baker, B H, Williams. I. A J, Miller, I A. and Fitch. IJ 1971, Sequence and geochronology of the Kenya Rilt voleanies: Tectonophysics, v. 11 pp. $191-215$

Bellieni, G, Brotu, R. Morbidelli, L, Piccirillo, E M, and Traversa, G, 1986, Petrology and mincralogy of Miocene fissural volcanism of the East Kenya Plateau: Neues Jahrbuch Mineralogice, v. 154, pp. 153-178. Bosworth, W, 1987, Ofl-axis voluanism in the Gregory Rift, East Africa: Implications for models of continental rifing: Goology, v. 15, pp. $397-400$.

Brown, C, (Gidder, R W. 1980 . Interpretation of African gravity and its implication for the break up of the continents: Journal of Geophysical Research, v. 85, pp. 6443-6445.

Cahen, L, Snelling, N J, Dethal, J, and Vail. J R, 1984, Phaneromoic anorogenic igneous activity in Arica in The geochronology and evolution of Alrica: Oxlord, Clarendon Press, pp. 375-418.

Chorowic\%, J, Le Foumier, J, and Vidal, G, 1987. A model for rift development in eatstern Airica: Geological Journal, v. 22, pp. 495-513.

Dawson, J B, 1992, Neogene tectonics and volcanicity in the north Tanzania sector of the Gregery Rift Valley: contrats with the Kenya sector: Teconophysics, v. $204, \mathrm{pp} .81-92$.

Ebinger, C J, 1989 , Tectonic development of the western branch of the East African Rifi system: Geological Sociely of Anerica Bulletin, v. 101, pp. $885-903$.

Fllis, $M$, and King, $G, 1991$, Structumal control of thank volcanism in continental rilts: Scicnec, v. 254, pp. 839-842.

Pairhead, J D, and Girdler, R W, 1971. The seismicity of Africa: Geophysical Journal of the Royal Astronomical Society, v. 24. pp. $271-301$

Gass. I G, Matlich, D I J, and Cox, K G, 1965, The Royal Society expedition to the South Arabian Iederalion: Nalure, London, V. 212, pp. $952-925$.

Gass, I G. Mallick, D I J, and Cox, K G, 1973, Volcanie islands of the Red Sea: Journal of the Geological Socicty of $[$ condon, 129, 275-310.

Girdler, R W, 1973, Discussion of "Volcanic islands of the Red Sea" Journal of the Cicologecal Society of London, v. 129, pp. 643-645.

Girdler. R W, 1983, Processes of planetary ribing as seen in the rifting and break up of Africa in P Morgan and B H Baker, eds., Processes of continental rifting: Tectonophysies, v. 94, pp. 241-252.

Girdler, R W, 1985, The East African Rilt system as a propagating rift system: International Symposium on Deep Internal Processes and Continental Rifting (DIPCR), Chengdu, Chinat. 1985, p. 46. (China, Acadenic Publishers).

Girdler, R W, 1991, The Afro-Arabian Rift system-an overview: in A F Gangi, ed., World Rift Systems: Tectonophysies, v. 197, pp. 139-153.

Girdler, R W, Fairhciad, J D, Scarle, R C, and Sowerbutts, W T C, 1969, The evolution of rifting in Africa: Nature, London, v. 224, pp. 1178-1182.

Gregory, J W, 1896, The Great Rifi Valley: John Murray, London.

Gregory, J W, 1921, The Rifi Valleys and Geology of East Africa: Seeley. Service Co. I.td, I ondon.

Gutenberg. B. and Richter, C. F. 1954. Scismicity of the Earth, second edition: Princelon University Press.

Hackman. B D, Charsley, T J, Key, R M, and Wilkinson, A F, 1990, The development of the East African Rifi system in norlh-ecnral Kenya: Teconophysics, v. 184, pp. 189-211. 
Jorgensen, G J, and Bosworth, W, 1989, Gravity modelling in the Central African Rift system, Sudan-Rift geometry and tectonic significance: Journal of African Earth Sciences v. 8, pp. 283-306.

Kazmin, V, Berhe, S M, Nicolleti, M, and Petrucciani, C, 1980, Evolution of the northern part of the Ethiopian Rift in Geodynamic evolution of the Afro-Arabian Rift System. Atti dei Convegni Lincei, Roma pp. 275-292.

King, B C, 1978, Structure and volcanic evolution of the Gregory Rift valley, in Bishop, W W, ed., Geological background to fossil man: Scottish Academic Press, Edinburgh, UK, pp. 29-54.

KRISP Working Group, 1991, Large-scale variation in lithospheric structure along and across the Kenya Rift: Nature, London, v. 354, pp. 223-227.

Loupekine, I S, 1971, Catalogue of felt earthquakes in Kenya 1892-1969: Seismology Unit, University of Nairobi, Kenya.

McClelland, L, Simkin, T, Summers, M, Nielsen and Stein, T C, 1989, Global volcanism 1975-1985: Prentice Hall, Englewood Cliffs, New Jersey.

McConnell, D A, 1991, The 1991 Sudan earthquake sequence. MSc dissertation, University of Newcastle upon Tyne, UK.

Mohr, P A, 1974, Mapping of the major structures of the African Rift system: NASA/Smithsonian Institution. Contract NAS 5-21748.

Mohr, P A, 1982, Musings on continental rifts, in Palmason, G, ed. Continental and oceanic rifts: Geodynamics Series, American Geophysical Union, Washington DC, USA, v. 8, pp. 293-309.

Morley, C K, 1988, Comment on 'Off-axis volcanism in the Gregory Rift. East Africa: Implications for models of continental rifting': Geology, v, 16, pp. 569.

Morley, C K, Wescott, W A, Stone, D M, Harper, R M, Wigger, S T, and Karanja, F M, 1992, Tectonic evolution of the northern Kenyan Rift: Journal of the Geological Society, v. 149, pp. 333-348.

Nyblade, A A, and Pollack, H N, 1992, A gravity model for the lithosphere in western Kenya and northeastern Tanzania: Tectonophysics, v. 212, pp. 257-267.

Richard, J J, and Neuman Van Padang, M. 1957, Catalogue of the active volcanoes of the world including solfatara fields, Part IV, Africa and the Red Sea: International Association of Volcanology, pp. 31-118.

Rosendahl, B R, 1987, Architecture of continental rifts with special reference to East Africa: Annual Review of Earth \& Planetary Sciences, v, 15, pp. 445-503.

SEAN (Seismic Event Alert Network): Smithsonian Institution, Washington, DC. Bulletin.

Searle, R C, 1970, Evidence from gravity anomalies for thinning of the lithosphere beneath the Rift Valley in Kenya: Geophysical Journal of the Royal Astronomical Society, v. 21, pp. 13-31.

Seuss, E, 1891, Die Bruche des ostlichen Afrika: Denkschriften der Kaiserlichsche Akademie der Wissenschaften zu Wein (MathematikNatukrwissenschaften), v. 58, pp. 555-584.

Simkin, T, Siebert, L, McClelland, L, Bridge, D, Newhall, C, and Latter, J H, 1981, Volcanoes of the World: A regional directory gazetteer and chronology of volcanism during the last 10000 Years: Hutchinson Ross Publishing Co., Stroudburg, PA, USA.

Simkin, T, Tilling, R I, Taggart, J N, Jones, W J and Spall, H, 1989, This dynamic planet, volcanoes, earthquakes and plate tectonics: Smithsonian Institution, Washington, DC, USA.

Smith, M, and Mosley, P N, 1993. Crustal heterogeneity and basement influence on the development of the Kenya Rift, East Africa: Tectonics, v. 12, no. 2, pp. 591-606.

Tongue, J A, Maguire, P K H, and Young, P A V, 1992, Seismicity distribution from temporary earthquake recording networks in Kenya: Tectonophysics, v. 204, pp. 71-79.

Walker, G P L, 1989, Gravitational (density) controls on volcanism, magma chambers and intrusions: Australian Journal of Earth Science, v. 36, pp. $149-165$.

Wilkinson, A F, 1988, Geology of the Allia Bay area: Kenya Mines and Geological Department Report 109.

Williams, L A J. 1972, The Kenya Rift volcanics: a note on volumes and chemical composition: Tectonophysics, v. 15, pp. 83-96.

Zanettin, B, Justin-Visentin, E, Nicoletti, M, and Picirillo, E M, 1980, Correlations among Ethiopian volcanic formations with special references to the chronological and stratigraphic problems of the Trap Series: in Geodynamic evolution of the Afro-Arabian Rift system: Atti dei Convegni Lincei, Roma pp. 231-252.

Listings of the volcanoes with locations (latitudes and longitudes) and simple descriptions may be obtained from the first author. $\square$

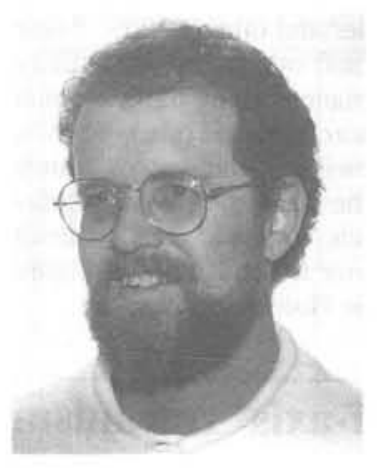

Robert Nusbaum is an Associate Professor of Geology at the College of Charleston, South Carolina, USA. His research interests over the past 15 years include the geochemistry of large-volume silicic magma chambers, the relationship between volcanism and tectonics, caldera evolution, ocean island volcanism and the rheology of thick lavas on Venus. He is also interested in educating future generations of earth scientists and serves as the South Carolina Space Grant Consortium campus director for the College of Charleston.

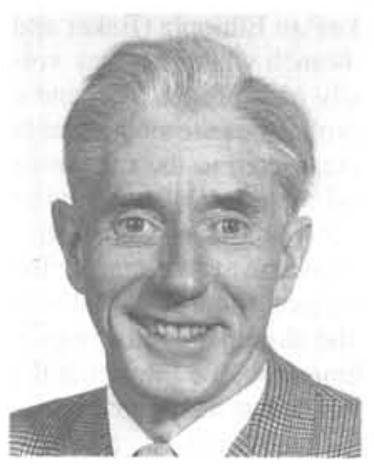

Ronald W Girdler is Reader in Geophysics at the University of Newcastle upon Tyne, UK. He gained his $P h D$ in geophysics at the University of Cambridge in 1959 and has spent periods in the USA at Columbia University and the NASA/Goddard Space Flight Center. He has worked extensively in East Africa, the Gulf of Aden, and the regions of the Red Sea and Dead Sea, specialising in the evolution of rifting, rift volcanism, and early stages of formation of continental margins and ocean basins. He is a fellow of the Royal Astronomical Society and Life Member of the American Geophysical Union and Society of Exploration Geophysics.

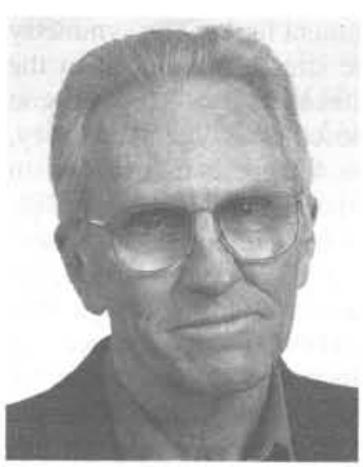

James $\mathbf{R}$ Heirtzler is a Staff Scientist for Geophysics in the Laboratory for Terrestrial Physics at NASA's Goddard Space Flight Center. He has encouraged the use of satellite remote sensing and geophysical data to study the East African Rift, one of the most geologically active areas on Earth. He views the East African Rift system as a close analogue to the Mid-Ocean Rift system, which he has studied for many years. In addition he sees satellite-borne remote-sensing instruments as the equivalents of seafloor mapping instruments, providing a realistic comparison on plate tectonic processes in the two different areas.

Of the other authors, Duncan Hutt is at the Department of Physics, University of Newcastle upon Tyne, while David Green, Victor Millings, Bradley Schmoll and Joel Shapiro are all at the Department of Geology, College of Charleston. 